\title{
PERILAKU SEKSUAL BERISIKO INFEKSI MENULAR SEKSUAL
}

\author{
Lenny Irmawaty Sirait ${ }^{1}$, Lisna Elisabeth ${ }^{2}$, Marni Br.Karo ${ }^{3}$ \\ Program Studi Kebidanan (D3) STIKes Medistra Indonesia ${ }^{123}$ \\ (e-mail): ${ }^{1}$ lennyirmawaty@gmail.com, \\ ${ }^{2}$ Lisnaelisaelisabeth@gmail.com, ${ }^{3}$ Marni_karo@yahoo.com
}

\begin{abstract}
Sexually Transmitted Infections (STIs) are various infections that can be transmitted from one person to another through sexual contact. The spread of STIs to women and men (90\%) occurs through sexual intercourse, both vaginal, anal and oral, the rest through blood products or tissue transfer that has been exposed to pathogens or can be transmitted through medical devices, as well as from mother to fetus in the womb or while birth process. This study aims to determine the relationship between sexual intercourse patterns and the incidence of sexually transmitted infections in women of reproductive age at the Makassar District Health Center, East Jakarta 2019. This research method is a type of quantitative research with a cross-sectional research design, using the inclusion and exclusion criteria for a sample of 55 people, the type of data. primer, measuring instrument questionnaire and laboratory results, analysis of chi square test data. The results showed that out of 46 women of childbearing age who had a poor pattern of sexual relations and sexually transmitted infections were 41 people (89.1\%) and 5 people (10.9\%) had sexually transmitted infections while 9 people had a pattern of sexual intercourse. well and sexually transmitted infections were 1 person (11.1) and sexually transmitted infections were 8 people (89.9\%) pvalue $=0.01$ ( $p$ <0.05). Conclusion The Relationship between Sexual Relationship Patterns and the Incidence of Sexually Transmitted Infection in Women of Fertile Age at the Makassar District Health Center 2019 ( $p$ value $=0.01$ )
\end{abstract}

Keywords: sexual intercourse behavior; sexually transmitted infections; women of childbearing age.

\begin{abstract}
ABSTRAK
Infeksi Menular Seksual (IMS) merupakan berbagai infeksi yang dapat menular dari satu orang ke orang yang lain melalui kontak seksual. Penyebaran IMS pada perempuan dan laki-laki (90\%) terjadi melalui hubungan seksual baik secara vaginal, anal dan oral selebihnya melalui produk darah atau transfer jaringan yang telah terpapar patogen atau dapat ditularkan melalui alat kesehatan, serta dari ibu kepada janin dalam kandungan atau saat proses kelahiran. Penelitian ini bertujuan untuk Mengetahui Hubungan Pola Hubungan Seksual Dengan Kejadian Infeksi Menular Seksual Pada Wanita Usia Subur di Puskesmas Kecamatan Makasar Jakarta Timur 2019. Metode penelitian ini merupakan jenis penelitian kuantitatif dengan desain penelitian cross sectional, menggunakan kriteria insklusi dan eksklusi sampel 55 orang, jenis data primer, alat ukur kuesioner dan hasil laboratorium, analisis data uji chi square. Hasil Penelitian diperoleh bahwa dari 46 orang wanita usia subur yang pola hubungan seksual nya buruk dan infeksi menular seksual nya positif sebanyak 41 orang $(89,1 \%)$ dan infeksi menular seksualnya negatif sebanyak 5 orang $(10,9 \%)$ sedangkan 9 orang yang pola hubungan seksual nya baik dan infeksi menular seksualnya positif sebanyak 1 orang $(11,1)$ dan infeksi menular seksualnya negatif sebanyak 8 orang $(89,9 \%)$ pvalue $=0,01$ ( $<<0,05)$. Kesimpulan Terdapat Hubungan Pola Hubungan Seksual dengan Kejadian Infeksi Menular Seksual pada Wanita Usia Subur di Puskesmas Kecamatan Makasar $2019(p$ value $=0,01)$

Kata kunci: prilaku hubungan seksual; infeksi menular seksual; wanita usia subur.
\end{abstract}

\section{PENDAHULUAN}

\section{Latar Belakang (Opsional)}

Infeksi Menular Seksual (IMS) termasuk dalam kelompok penyakit menular. Selain infeksi HIV, IMS telah menimbulkan beban morbiditas dan mortalitas terlebih di negara sedang berkembang dimana sumber daya terbatas karena secara langsung berdampak pada kualitas hidup, kesehatan reproduksi dan anak-anak, dan secara tidak langsung mempermudah transmisi seksual infeksi HIV dan dampaknya terhadap perekonomian perorangan maupun nasional (1). IMS menempati peringkat 10 besar alasan berobat di banyak negara berkembang, dan biaya yang dikeluarkan dapat mempengaruhi pendapatan rumah tangga. Pelayanan untuk komplikasi atau sekuele IMS mengakibatkan beban biaya yang tidak sedikit, misalnya untuk skrining dan pengobatan kanker serviks, penanganan penyakit jaringan hati, pemeriksaan infertilitas, pelayanan morbiditas perinatal, kebutaan bayi, penyakit paru pada anakanak, serta nyeri panggul kronis pada wanita. Beban sosial meliputi konflik dengan pasangan seksual dan dapat mengakibatkan kekerasan dalam rumah tangga.

Penyebaran IMS pada perempuan dan lakilaki $(90 \%)$ terjadi melalui hubungan seksual baik secara vaginal, anal dan oral selebihnya melalui produk 
darah atau transfer jaringan yang telah terpapar patogen atau dapat ditularkan melalui alat kesehatan, serta dari ibu kepada janin dalam kandungan atau saat proses kelahiran. Diketahui lebih dari 30 jenis patogen (bakteri, virus, parasit, jamur) dapat ditularkan melalui hubungan seksual dengan manifestasi klinis yang berbeda sesuai jenis kelamin dan umur. Pada area geografis tertentu patogen IMS ditularkan di antara atau dari individu berisiko tinggi dengan angka infeksi yang tinggi dan kekerapan berganti-ganti pasangan seksual (kelompok inti atau core group). Dengan perkembangan epidemi, patogen dapat menyebar dari kelompok inti kepada populasi pelanggan (populasi antara, bridging population), yang menjadi perantara penting lintas seksual antara kelompok inti dan populasi umum. Pada gilirannya populasi antara akan menularkan penyakitnya kepada pasangan seksual lainnya, misalnya suami/isterinya ataupun pasangan seksual tetap di dalam populasi umum (Kementerian Kesehatan RI, 2016).

Penularan IMS secara umum terjadi akibat perilaku seksual berisiko. IMS yang dapat disembuhkan dan yang tidak dapat disembuhkan terus meningkat, meskipun strategi pencegahan diterapkan hingga saat ini. Wanita seringkali memiliki tingkat IMS tertinggi dan menyebabkan jumlah infeksi baru yang tidak proporsional. IMS seringkali tanpa gejala. Meskipun kerentanannya lebih besar, pilihan saat ini untuk mengurangi penyebaran IMS tetap terbatas untuk perempuan.

Beban sosial yang diakibatkan IMS yaitu konflik pasangan seksual dan dapat menyebabkan kekerasan dalam rumah tangga. Infeksi menular seksual merupakan penyebab kemandulan yang paling dapat dicegah, terutama pada perempuan. Antara 10\%$40 \%$ perempuan dengan infeksi Chlamydia yang tidak diobati akan mengalami penyakit radang panggul (PRP). Kerusakan tuba falopii pasca infeksi berperan dalam kasus kemandulan perempuan (30\%-40\%). Terlebih lagi, perempuan dengan PRP berkemungkinan 6-10 kali mengalami kehamilan ektopik dibandingkan dengan yang tidak menderita PRP, dan 40\%-50\% kehamilan ektopik disebabkan oleh PRP yang diderita sebelumnya. Infeksi menular seksual yang tidak diobati seringkali dihubungkan dengan infeksi kongenital atau perinatal pada neonatus, terutama di daerah dengan angka infeksi yang tinggi. Perempuan hamil dengan sifilis dini yang tidak diobati, sebanyak $25 \%$ mengakibatkan janin lahir mati dan 14\% kematian neonatus, keseluruhan menyebabkan kematian perinatal sebesar $40 \%$. Kehamilan pada perempuan dengan infeksi gonokokus yang tidak diobati, sebesar 35\% akan menimbulkan abortus spontan dan kelahiran prematur, dan sampai $10 \%$ akan menyebabkan kematian perinatal. Dalam ketiadaan upaya pencegahan, $30 \%$ sampai $50 \%$ bayi yang lahir dari ibu dengan gonore tanpa pengobatan dan sampai $30 \%$ bayi yang lahir dari ibu dengan klamidiosis tanpa diobati, akan mengalami oftalmia neonatorum yang dapat mengakibatkan kebutaan penyakit dewasa yang membutuhkan pelayanan kesehatan yang memberi dampak besar pada kesehatan seksual dan reproduksi (2).

Angka kejadian paling tinggi tercatat di Asia Selatan dan Asia Tenggara, diikuti Afrika bagian Sahara, Amerika Latin, dan Karibean. Prevalensi IMS di negara berkembang jauh lebih tinggi dibandingkan dengan di negara maju. Pada perempuan hamil di dunia, angka kejadian gonore $10-15$ kali lebih tinggi, infeksi klamidia 2 - 3 kali lebih tinggi, dan sifilis $10-$ 100 kali lebih tinggi jika dibandingkan dengan angka kejadiannya pada perempuan hamil di negara industri. Pada usia remaja (15 - 24 tahun) merupakan 25\% dari semua populasi yang aktif secara seksual, memberikan kontribusi hampir 50\% dari semua kasus PMS baru yang didapat. Kasus-kasus IMS yang terdeteksi hanya menggambarkan 50\% - 80\% dari semua kasus IMS yang ada di Amerika. Ini mencerminkan keterbatasan "screening" dan rendahnya pemberitaan akan IMS (Sarwono, 2011). Data dari profil pengendalian penyakit dan penyehatan lingkungan di Indonesia tahun 2012 didapatkan total kasus IMS yang ditangani pada tahun 2012 sebanyak 140.803 kasus dari 430 layanan IMS. Menurut hasil STBL 2011 ada tiga Provinsi Jawa Barat sebagai provinsi dengan angka HIV dan IMS yang cukup tinggi setelah Jawa timur dan Bali. Di Indonesia Jumlah kasus IMS terbanyak berupa cairan vagina abnormal (klinis) 20.962 dan servicitis (lab) 33.025. IMS merupakan salah satu pintu masuk atau tanda-tanda adanya HIV (Kemenkes, 2013).

Dalam berhubungan seksual akan terjadi perlukaan pada jaringan sehingga melalui luka tersebut virus dapat masuk dan menginfeksi tubuh. Untuk itu sangat penting pemakaian kondom secara konsisten. Perilaku oral dan anal dalam berhubungan seksual merupakan perilaku yang sangat berisiko terhadap terjadinya IMS.

Penularan utama infeksi menular seksual ialah melalui hubungan seksual. Setiap orang yang telah aktif secara seksual memiliki resiko terkena infeksi menular seksual. Peningkatan insidensi infeksi menular seksual selalu berkaitan dengan perilaku seksual beresiko tinggi.

Jumlah kasus IMS di Indonesia sampai bulan desember tahun 2017 mengalami kenaikan dari tahun 2015 sampai 2017 dengan jumlah kasus 2015 yaitu 30.935, pada tahun 2016 sebanyak 41.250 dan pada tahun 2017 mengalami kenaikan menjadi 48.300 kasus pertahunnya (3). Data DKI Jakarta pada tahun 2017 menurut jenis kelamin pada laki-laki sebanyak 18.598 kasus dan pada perempuan sebanyak 11.411 kasus selama tahun 2017, kasus ims mengalami kenaikan setiap tahun dari tahun 2015 sampai 2017 yaitu pada tahun 20154.695 , pada tahun 2016 6.019, dan pada tahun 2017 sebanyak 6.626 kasus (3)(4). Melihat dari berbagai permasalahan yang telah dipaparkan diatas, maka peneliti tertarik untuk mengkaji permasalahan tersebut dan mengadakan penelitian dengan judul "Hubungan Pola Hubungan Seksual dengan Kejadian 
Infeksi Menular Seksual pada Wanita Usia Subur di Puskesmas Kecamatan Makasar Jakarta Timur 2019”.

\section{Tujuan Penelitian (Opsional)}

Penelitian ini bertujuan untuk mengetahui Hubungan Pola Hubungan Seksual Dengan Kejadian Infeksi Menular Seksual Pada Wanita Usia Subur di Puskesmas Kecamatan Makasar Jakarta Timur 2019.

\section{Hipotesis (Opsional)}

Hipotesi penelitian diberdirikan sebagai berikut:

1. Hipotesis nol (Ho)

"Tidak ada Hubungan prilaku hubungan seksual Dengan Kejadian Infeksi Menular Seksual Pada Wanita Usia Subur di Puskesmas Kecamatan Makasar Jakarta Timur 2019".

2. Hipotesis Alternatif (Ha)

"Ada Hubungan pola hubungan seksual Dengan Kejadian Infeksi Menular Seksual Pada Wanita Usia Subur di Puskesmas Kecamatan Makasar Jakarta Timur 2019”.

\section{METODE}

Penelitian ini merupakan jenis penelitian kuantitatif dengan desain penelitian cross sectional, yaitu desain untuk melihat hubungan antara variabel independen atau variabel bebas. Dilakukan dengan pengukuran pada saat bersamaan, sehingga dapat mengetahui Hubungan perilaku Hubungan Seksual dengan Kejadian Infeksi Menular Seksual Pada Wanita Usia Subur di Puskesmas Kecamatan Makasar 2019.

Populasi pada penelitian ini adalah seluruh wanita usia subur yang melakukan pemeriksaan di poli IMS pada bulan januari - maret sebanyak 97 WUS di Puskesmas Kecamatan Makasar. Sampel pada penelitian ini adalah Wanita Usia Subur di Puskesmas Kecamatan Makasar. Untuk menentukan besar sampel di Puskesmas Kecamatan Makasar digunakan rumus slovin sebagai berikut :

$$
\begin{aligned}
& \mathrm{n}=\frac{N}{1+N d^{2}} \\
& \mathrm{~N}: \text { Ukuran Populasi } \\
& \mathrm{n}: \text { Ukuran Sampel } \\
& \mathrm{d}: \text { Tingkat kepercayaan/ketetapan yang } \\
& \text { diinginkan }(0,1)(5) \\
& \mathrm{n}=\frac{N}{1+N d^{2}} \\
& \mathrm{n}=\frac{97}{1+97(0,1)^{2}} \\
& \mathrm{n}=\frac{97}{1+0.97} \\
& \mathrm{n}=\frac{97}{1,97} \\
& \mathrm{n}=49,2
\end{aligned}
$$

Maka, dari perhitungan dengan rumus diatas maka sampel diambil sebanyak 50 orang. Untuk mengantisipasi jika dari hasil perhitungan tersebut tidak memenuhi target yang akan dicapai,misalnya dikarenakan ada kuesioner yang tidak lengkap diisi oleh responden, kuesioner hilang dan sebagainya maka besar sampel yang ditambahkan $10 \%$ dari total sampel,yaitu menjadi 55 orang responden. Teknik Pengambilan Sampel ini adalah menggunakan Teknik Purposive Sampling dimana sampel diambil melalui kriteria insklusi dan kriteria ekslusi sebanyak 55 orang responden. Pengambilan sampel menggunakan Teknik Purposive Sampling karena keterbatasan waktu penelitian untuk meneliti di Puskesmas Kecamatan Makasar.

Variabel penelitian terdiri dari variabel independen yaitu perilaku hubungan seksual dan variabel dependen yaitu kejadian infeksi menular seksual. Terdapat dua teknik pengumpulan data yang dalam penelitian ini yaitu pengumpulan data sekunder dengan cara memperoleh data dari tempat penelitian berupa data hasil laboratorium di Poli IMS Puskesmas Kecamatan Makasar dan pengumpulan data primer dengan cara penyebaran kuesioner pada responden yang berisi pertanyaan tentang informasi yang ingin diketahui sesuai dengan tujuan penelitian.

Analisi data terdiri dari analisis univariat yaitu untuk melihat distribusi frekuensi masing-masing variabel. Adapun variabel yang akan dilakukan analisis univariat yaitu variabel independen yaitu prilaku hubungan seksual dan variabel dependen yaitu kejadian infeksi menular seksual di Puskesmas Kecamatan Makasar 2019. Selanjutnya analisis bivariat untuk melihat ada tidaknya hubungan antara variabel independen dengan variabel dependen.Untuk mencari hubungan antara variabel independen maka digunakan uji statistic chi Square. Hasil uji statistik antara variabel independen dengan variabel dependen dikatakan ada hubungan yang bermakna bila nilai $\mathrm{p} \leq$ 0,05 dan sebaliknya bila nilai $\mathrm{p}>0,05$ itu artinya tidak ada hubungan yang bermakna

\section{HASIL}

\section{Karakteristik Responden Penelitian}

Tabel 1. Karakteristik Responden

\begin{tabular}{|l|l|l|}
\hline \multicolumn{1}{|c|}{$\begin{array}{c}\text { Karakteristik } \\
\text { Responden }\end{array}$} & \multicolumn{1}{c|}{ F } & \multicolumn{1}{c|}{ \%5 } \\
\hline Usia & 16 & \\
$15-25$ & 22 & 29,1 \\
$26-35$ & 13 & 40 \\
$36-45$ & 2 & 23,6 \\
$46-55$ & 2 & 3,6 \\
$56-65$ & & 3,6 \\
\hline Pendidikan & 1 & \\
SD & 7 & 1,8 \\
SMP & 36 & 12,7 \\
SMA & 1 & 65,5 \\
D3 & 10 & 1,8 \\
S1 & & 18,2 \\
\hline Pekerjaan & 31 & \\
IRT & 2 & 56,4 \\
Wiraswasta & 13 & 3,6 \\
Karyawan Swasta & 2 & 3,6 \\
Mahasiswa & 1 & 1,8 \\
PSK & 2 & 3,6 \\
Guru & &
\end{tabular}


Vol. 16 No. 1 Januar i - April 2021

\begin{tabular}{|l|l|l|}
\hline Pedagang & 1 & 1,8 \\
Security & 1 & 1,8 \\
PNS & 1 & 1,8 \\
SPG & 1 & 1,8 \\
\hline
\end{tabular}

Berdasarkan tabel 1, karakteristik usia responden mayoritas 26-35 tahun sebanyak 22 (40\%), pendidikan mayoritas SMA sebanyak $36(65,5 \%)$ dan pekerjaan mayoritas IRT yaitu $31(56,4 \%)$ responden.
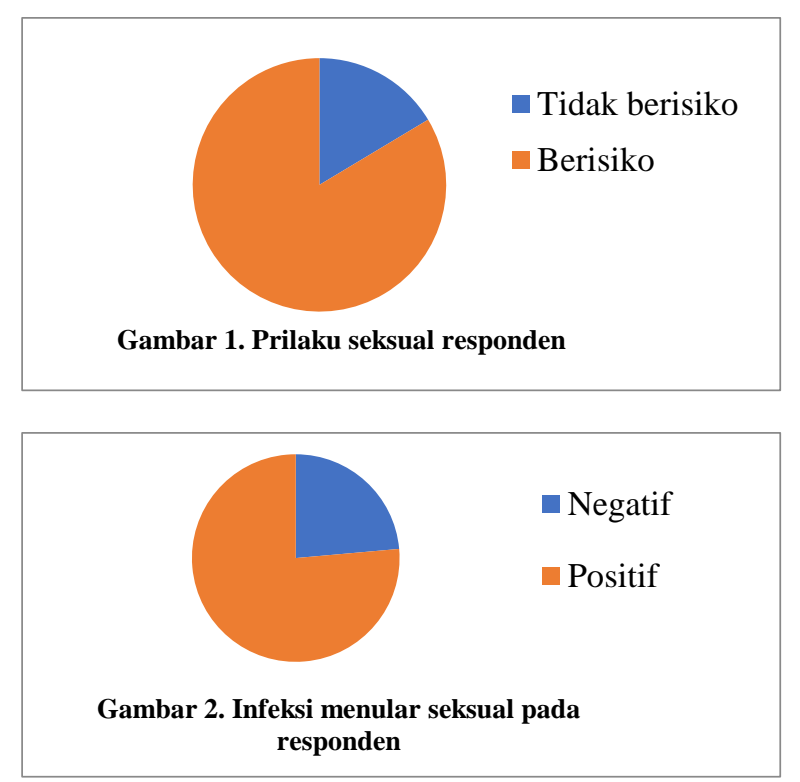

Gambar 1 menjelaskan bahwa perilaku hubungan seksual responden sebagian besar berisiko sebanyak 46 $(83,6 \%)$ dan sebagian besar positif infeksi menular seksual yaitu $42(76,4 \%)$ responden.

Tabel 2. Hubungan Perilaku Hubungan Seksual dan Infeksi Menular Seksual

\begin{tabular}{|l|c|c|c|c|c|c|c|}
\hline \multirow{2}{*}{$\begin{array}{c}\text { Perilaku } \\
\text { Hubungan } \\
\text { Seksual }\end{array}$} & \multicolumn{4}{|c|}{$\begin{array}{c}\text { Infeksi Menular } \\
\text { Seksual }\end{array}$} & \multicolumn{2}{|c|}{ Total } & \multirow{2}{*}{$\begin{array}{c}\text { P } \\
\text { Value }\end{array}$} \\
\cline { 2 - 7 } & \multicolumn{2}{|c|}{ Positif } & \multicolumn{2}{|c|}{ Negatif } & \multicolumn{2}{|c|}{} \\
\cline { 2 - 7 } & $\mathrm{n}$ & $\%$ & $\mathrm{n}$ & $\%$ & $\mathrm{n}$ & $\%$ & \\
\hline $\begin{array}{l}\text { Tidak } \\
\text { Berisiko }\end{array}$ & 1 & 11,1 & 8 & 89,9 & 9 & 16,4 & \multirow{2}{*}{0,01} \\
\hline Berisiko & 41 & 89,1 & 5 & 10,9 & 46 & 83,6 & \\
\hline & 42 & 76,4 & 13 & 23,6 & & & \\
\hline
\end{tabular}

Tabel 2 menunjukkan bahwa sebagian besar responden positif infeksi menular seksual memiliki prilaku hubungan seksual berisiko. $\mathrm{P}$ value sebesar $0,01 \quad(<$ $0,05)$ artinya terdapat hubungan yang bermakna antara perilaku hubungan seksual dengan infeksi menular seksual.

\section{PEMBAHASAN}

Penelitian ini telah membuktikan bahwa terdapat hubungan yang bermakna antara perilaku hubungan seksual dengan infeksi menular seksual. Perilaku seksual merupakan segala tingkah laku yang didorong oleh hasrat seksual baik dengan lawan jenis maupun sesama jenis. Melakukan hubungan seksual yang berisiko meningkatkan infeksi menular seksual (IMS) dan Human Immunodeficiency Virus (HIV) (Toding, 2012). Penularan IMS secara umum terjadi akibat perilaku seksual berisiko, sehingga di sebabkan individu dalam situasi yang rentan terhadap infeksi.Perilaku seksual yang berisiko infeksi menular seksual pada penelitian ini diantaranya memiliki lebih dari 1 pasangan dalam berhubungan seksual; sebelum dan sesudah melakukan hubungan seksual tidak membersihkan organ kewanitaan dengan pembersih/pembasuh organ kewanitaan; melakukan hubungan seksual menggunakan tanpa kondom; melakukan hubungan seksual lebih dari 2x dalam seminggu.

Hal ini sejalan dengan penelitian (6) bahwa wanita pekerja seksual yang berhubungan tidak selalu menggunakan kondom mempunyai peluang 5.58 kali mengalami IMS dibanding yang menggunakan kondom. Perilaku responden seperti hubungan seks yang berganti-ganti, konsistensi perilaku seks dengan menggunakan pelindung atau kondom, faktor pendorong untuk bertindak berasal dari kesadaran sendiri untuk memeriksakan kesehatan, defisit pengetahuan dan tidak adanya dukungan keluarga dalam pencegahan sehingga mengalami IMS (7). Teori L. Green menyatakan bahwa faktor penguat (reinforcing factor) memberikan dukungan untuk memperkuat perubahan perilaku seseorang untuk bertindak dari pengaruh orang lain. Membersihkan kemaluan terutama saat sebelum maupun sesudah melakukan hubungan seksual menggunakan air bersih, melakukan hubungan seksual hanya dengan satu pasangan dan melakukan hubungan seksual dengan frekuensi yang sewajarnya merupakan perilaku mencegah terjadinya IMS (8).

Penelitian ini sedikit berbeda dengan penelitian (9) tentang penggunaan sabun kewanitaan \$ebagai pembersih vagina mengungkapkan bahwa \$ebagian besar informan membersihkan alat kelamin dengan air bersih dan sabun pembersih kewanitaan sedangkan 1 informan membersihkan kelamin dengan pasta gigi. Cara membersihkan alat kelamin yaitu dengan "mengkorek-korek" vagina bagian dalam baik dengan sabun maupun pasta gigi. Informan menganggap kuman akan mati apabila alat kelamin dibersihkan dengan sabun pembersih kewanitaan ataupun dengan pasta gigi. Pendapat atau anggapan yang tidak benar namun berkembang di lokalisasi dapat mengakibatkan terhambatnya perubahan perilaku positif dalam mencegah IMS. Sabun pembersih kewanitaan dan pasta gigi tidak seharusnya digunakan untuk vagina bagian dalam karena dapat merusak vagina, serta merusak keseimbangan $\mathrm{pH}$ sehingga flora normal yang berada di vagina bisa mati dan membuat patogen penyebab IMS justru berkembangbiak. Informan tidak begitu memperhatikan jenis kain celana dalam yang digunakan. Pemilihan jenis kain celana dalam yang 
mudah menyerap keringat dan tidak lembab bertujuan agar tidak terjadinya perkembangan bakteri patogen penyebab IMS. Frekuensi mengganti celana dalam dan pembalut merupakan salah satu bagian dari vaginal higiene. Informan utama sudah memenuhi frekuensi minimal dalam mengganti celana dalam dan pembalut, yaitu minimal 2 kali dalam sehari untuk celana dalam dan minimal 3 kali dalam sehari untuk penggantian pembalut. Hal ini perlu dilakukan untuk menghindari alat kelamin dalam keadaan lembab dan tidak membuat bakteri patogen menyebab IMS berkembangbiak Menyetrika celana dalam setelah dicuci. Informan menyatakan bahwa mereka selalu mengeringkan alat kelamin setelah buang air kecil/buang air besar, serta informan menggunakan celana dalam yang tidak ketat. Meskipun informan yang menyetrika celana dalam, mengeringkan alat kelamin dan menggunakan celana dalam yang tidak ketat belum mengetahui manfaat dari vaginal higiene yang telah mereka lakukan, tetapi secara tidak langsung mereka telah berperilaku

Penulisan sitasi harus mengikuti gaya

Vancouver dalam posisi superscript seperti ini.(1) Penulisan sitasi harus mengikuti gaya Vancouver dalam posisi superscript seperti ini. ${ }^{(2)}$ Penulisan sitasi harus mengikuti gaya Vancouver dalam posisi superscript seperti ini. ${ }^{(2)}$

\section{KESIMPULAN}

Perilaku hubungan seksual berisiko terhadap terjadinya infeksi menular seksual (IMS). Seharusnya Wanita usia subur melakukan perilaku hubungan seksual yang sehat sehingga terhindar dari IMS diantaranya membersihkan daerah kemaluan sebelum dan sesudah melakukan hubungan seksual menggunakan air bersih, kemudian berhubungan seksual dengan satu pasangan dan melakukan hubungan seksual dengan frekuensi yang sewajarnya dengan benar.

\section{DAFTAR PUSTAKA}

1. Kementerian Kesehatan Republik Indonesia. Buku Pedoman Nasional Tatalaksana IMS. 2016.

2. Simbolon WM, Budiarti W. Kejadian Infeksi Menular Seksual pada Wanita Kawin di Indonesia dan Variabel-variabel yang Memengaruhinya. Kesehat Reproduksi. 2020;7(2):81-7.

3. Kemenkes RI 2018. Profile Kesehatan Indonesia Tahun 2017. Ministry of Health Indonesia. 2018. 107-108 p.

4. Dinas Kesehatan Provinsi DKI Jakarta. Profil Kesehatan DKI JAKARTA Tahun 2017. Profil Kesehat DKI Jakarta tahun 2017. 2017;(4):156.

5. Widya N. Gambaran Tingkat Pengetahuan dan Perilaku Menjaga Kebersihan Organ Genetalia Eksternapada Siswi MI Pembangunan. 2014;

6. Puspita L. INFEKSI MENULAR SEKSUAL PADA WANITA PEKERJA SEKSUAL. 2017;2(1):31-44.

7. Refti WG. Faktor Resiko yang Berhubungan dengan Kejadian Infeksi Menular Seksual (IMS) di Klinik Voluntary Counseling Test (VCT). J Aisyah J Ilmu Kesehat. 2018;3(1):47.

8. Nari J, Shaluhiyah Z, Nugraha P. Analisis FaktorFaktor yang Berhubungan dengan Kejadian IMS pada Remaja di Klinik IMS Puskesmas Rijali dan Passo Kota Ambon. J Promosi Kesehat Indones. 2015;10(2):131-43.

9. Dessi Aryani MDNAN. Perilaku Pencegahan Infeksi Menular Seksual Pada Wanita Pekerja Seksual Kabupaten Tegal. J Kesehat Masy. 2015;10(2):160. 